\title{
車両排出揮発性ナノ粒子の詳細物性*
}

\author{
久保修一*1, 茶谷聡*2, 近藤照明*2 \\ 山本正美*2, 井上雅 枝*2
}

\section{Detailed Properties of Diesel Volatile Nanoparticles}

\author{
Shuichi KUBO*3, Satoru CHATANI, Teruaki KONDOH, \\ Masami YAMAMOTO and Masae INOUE \\ ${ }^{* 3}$ Toyota Central Research \& Development Laboratories, Inc., \\ 41-1 Yokomichi, Nagakute, Aichi, 480-1192 Japan
}

\begin{abstract}
This study was focused on the volatile nanoparticles consisting of hydrocarbons under idling and deceleration conditions. Diesel nanoparticles were collected on aluminum substrates using an impactor (MOUDI and Nano-MOUDI) and were analyzed with a gas chromatography-mass spectrometry (GC/MS) and a time- ${ }^{-}$-flight secondary ion mass spectrometry (TOF-SIMS). Main components of the volatile nanoparticles under idling and deceleration conditions were some combi. nation of the lubricating oil and the fuel heavy hydrocarbons $\left(>\mathrm{C}_{19}\right)$. Oxygenated fuel hydrocarbons and $>C_{35}$ lubricating oil hydrocarbons which had lower volatility than the main components had were detected in the volatile nanoparticles under idling and deceleration conditions respectively. We could simulate the volatile nanoparticles were formed via homogeneous nucleation of these lower volatile molecules, considering the existence of the lower volatile molecules in engine-out exhaust. It was concluded that the lower volatile molecules (oxygenated fuel hydrocarbons and $>\mathrm{C}_{35}$ lubricating oil hydrocarbons) were nucleation materials and the formation of the volatile nanoparticles consisting of hydrocarbons was dominated by homogeneous nucleation.
\end{abstract}

Key Words: Diesel Engine, Nucleation, Condensation, Nanoparticle, Diesel Fuel, Hydrocarbons

\section{1. 粕言}

ディーゼルエンジン車両から排出される粒子状物 質には，大きく分けて固体と揮発性物質から構成され る粒子が存在することが知られている. 固体粒子は, 主に $25 \mathrm{~nm}$ 前後の炭素状一次粒子の凝集体構造を有し ているススが主体である. ススの粒径分布は, 燃焼状 態に依存するが，現状のエンジンシステムでは $50 \mathrm{~nm}$ 〜100nm 近傍に数濃度ピークを持つ対数正規分布を示 し, "Accumulation mode” と呼ばれている.これに対 して, 揮発性粒子に関しては, 燃料, エンジンオイル

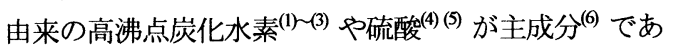
ることがわかってきている.これらの揮発性粒子の生 成は, 雰囲気温度, 希釈率, 滞留時間, 湿度及びスス 濃度に大きく依存して変化する(7) ことより, ススが 生成するエンジン筒内よりも下流で進行すると考えら れる. このため, 揮発性粒子の粒径分布は, ススの粒 径分布より低粒径側（30nm 以下）に数濃度ピークを

* 原稿受付 2006 年 3 月 1 日。

*1 正員, (株) 豊田中央研究所機械分野制御研究窒 (严 480-1192 愛知県長久手町湫横道 41-1)

*2 (株) 豊田中央研究所機械分野制御研究室.

E-mail : syu-kubo@mosk.tytlabs.co.jp
持ち, " Nucleation mode” と呼ばれている. また，揮 発性粒子の粒径が一般的に $30 \mathrm{~nm}$ 以下であることより, 揮発性ナノ粒子とも呼ばれている. しかし，このよう な揮発性ナノ粒子を強制的に蒸発させると完全蒸発せ ずに数 $\mathrm{nm}$ の固体核が残存することを示した報告(9) (10) により, 揮発性ナノ粒子が $100 \%$ 揮発性物質で構成さ れていない可能性が指摘され始めた. 揮発性ナノ粒子 に固体核が存在するかどうかは，生体に及ぼす影響度 が全く異なるため, 更なる検討が必要であると考えら れる.

本研究では, 燃料及びエンジンオイル由来の揮発 性ナノ粒子に着目し, 詳細な物性解析と理論解析を通 して車両から排出される揮発性ナノ粒子の生成メカニ ズムについて検討した.

\section{2. 実䀫}

2 -1 エンジン実検および柆子計瀄 ディーゼルエ ンジン車両から排出されるナノ粒子を解析するために 使用したエンジン実験および粒子計測の概要を図 1 に 示す. エンジンは, 4 気筒コモンレール式直噴ディー ゼルエンジン（排気量 : $2,000 \mathrm{~cm}^{3}$ ) が用いられ, エン 


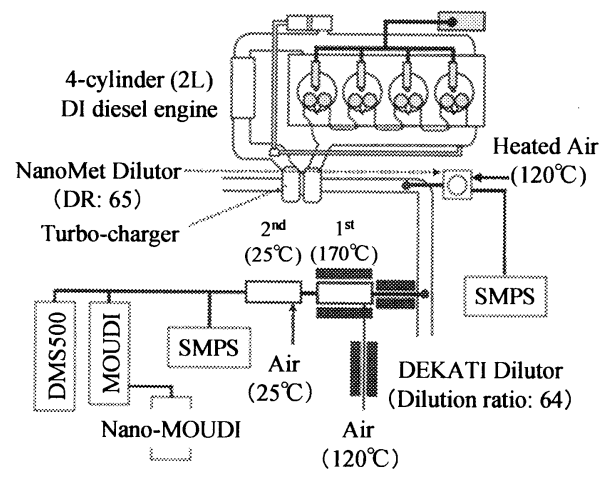

Fig. 1 Overall set-up of experimental apparatus

Table 1 Fuel properties

\begin{tabular}{cc}
\hline Property & Test Fuel \\
\hline Density @ 15 deg.C, kg/L & 0.8312 \\
Cetane Index & 55 \\
Aromatics, vol\% & 27.6 \\
Sulfur, wt ppm & 430 \\
Distilation, deg. C & \\
$10 \%$ & 214.5 \\
$30 \%$ & 248.0 \\
$50 \%$ & 271.5 \\
$70 \%$ & 297.5 \\
$90 \%$ & 331.5 \\
End Point & 370.5 \\
\hline
\end{tabular}

ジン回転数およびトルクはダイナモメータで制御され た.

定常運転時における粒子計測は, NanoMet 希釈器

(Matter Enginerring MD19-2E) と SMPS (TSI, DMA 3080, CPC 3025A）を組み合わせた構成を用いた. 過渡運転時 においては, 高速粒径分布計測装置（Cambustion, DMS500) とエジェクタ方式 2 段希釈器（DEKATI, DI1000）の組み合わせで実施した．配管は，配管からのガ ス放出をなくすために, $50^{\circ} \mathrm{C}$ 以上に温度が高くなる部位 にはステンレス管を使用し，室温近傍の部分には導電性 シリコンチューブ又はタイゴンチューブを使用した。

NanoMet 希釈器の希釈条件に関しては, 希釈器内におい てナノ粒子生成又は凝集が進行しないように希釈率は 65 倍, 希釈器及び希釈ガス温度は $120^{\circ} \mathrm{C}$ 設定された.

今回の解析で使用した燃料は，燃料起因のナノ粒子が 高い数濃度で安定に生成することが確認されている表 1 に示した性状のものである.

2-2 ナノ柆子成分分析法 ナノ粒子の物性を詳細に 解析するために, 希釈排気中に存在する粒子を粒径別に 分級してアルミニウム䇴上に捕集することができる MOUDH+Nano-MOUDI (MSP, MOUDI: Model 110, NanoMOUDI: Modd 115）を使用した. 粒子の捕集時間は,
$50 \mathrm{~nm}$ 以下の粒径区分において $10 \mu \mathrm{g}$ 程度の捕集量が確保 できるように，5時間実施した. アルミニウム箔上に捕 集された粒子は, 溶媒抽出操作を必要としない加熱脱着 GCMS（HP,GC:689,MS:5973）およびTOF-SIMS（飛行時 間型一二次イオン化質量分析, Physical Electronics, TFS 2100）を用いて分析された.

2-3 理望解析手法 ナノ粒子の生成メカニズムを詳 細に解析するために, エンジン実験結果を用いて理論計 算を実施した.

本計算モデルは，揮発性物質の粒子生成・成長に関わ る現象として, 凝集, 凝縮/蒸発, 核生成の 4 種類を考 慮したものを用いた.

凝集は，粒子同士の衝突，合体による粒径および粒子 数変化を (1) 式 ${ }^{(1)}$ で表した. 本モデルでは, $\beta$ としてブ ラウン運動による凝集を考慮し, Fuchs の凝集速度定数 ${ }^{(1)}$ を用いた. 凝縮／蒸発による粒径区分 $k$ の重量濃度 $m_{k}$ の 時間変化は (2) 式で表した. 核生成には古典的核生成理

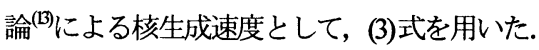

凝集については半陰解法, 凝縮／蒸発と核生成には陽 解法を用い，計算ステップ毎に別々に解いた.

$$
\begin{aligned}
& \frac{\partial N_{k}}{\partial t}=\frac{1}{2} \sum_{j=1}^{k-1} \beta_{k-j, j} N_{k-j} N_{j}-N_{k} \sum_{j=1}^{n} \beta_{k, j} N_{j} \\
& \frac{\partial m_{k}}{\partial t}=2 \pi D_{i} D_{p k} N_{k} f\left(K n_{k}, \alpha\right)\left[c-c^{e q} \eta_{k}\right] \\
& J=\left(\frac{2 \sigma}{\pi m_{1}}\right)^{1 / 2} \frac{v_{1} N_{1}^{2}}{S} \exp \left[-\frac{16 \pi}{3} \frac{v_{1}^{2} \sigma^{3}}{\left(k_{B} T\right)^{3}(\ln S)^{2}}\right]
\end{aligned}
$$

\section{略号の説明を以下に示す.}

$k$ : 粒径区分番号, $N$ : 数濃度, $\beta$ : 凝集速度定数, $m$ : 重量濃度, $D_{i}$ : 拡散定数, $D_{p}$ : 粒径, $f$ : 非連続領 域補正関数, $K n:$ Knudsen 数, $\alpha$ : accommodation 定数, $c$ :ガス濃度, $c^{e q}$ :平衡ガス濃度, $\eta:$ Kelvin 補正係数, $J$ : 核生成速度, $\sigma$ : 表面張力, $N_{1}, v_{1}, m_{1}$ : 分子の数, 体積, 重量, $S$ : 過飽和度, $k_{B}$ : Boltzmann 定数

ここで， $\alpha$ は 1.0 と仮定し， $c^{q q}:$ は複数成分の相互溶解 による活量係数等は扱わず，単純に飽和蒸気圧から求め た.

\section{3. 结果およひ考宗}

3-1 炭化水素起因ナノ粒子の生成特性 ディーゼル エンジン車両から排出されるナノ粒子のうちアイドリン グ時および減速時に観測されるものは，燃料成分の高沸 点炭化水素およびエンジンオイル成分の炭化水素が主成 分のナノ粒子であることは明らかとなっているの。 しか 


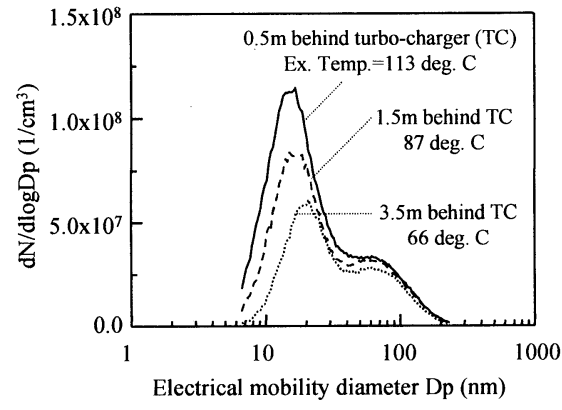

Fig.2 Change of number weighted particle size distributions in an exhaust pipe under idling condition

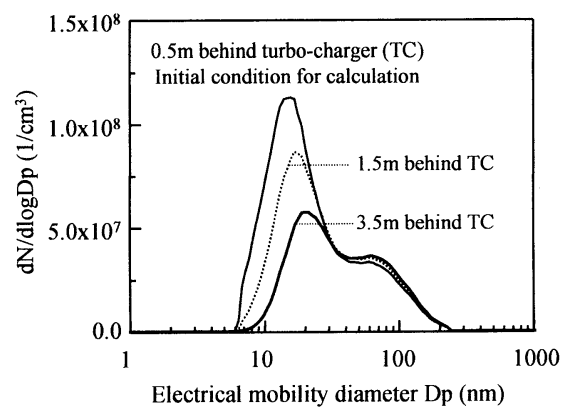

Fig.3 Coagulation simulation result for the evolution of change of particle size distribution in an exhaust pipe under idling condition

し，炭化水素起因のナノ粒子に関する詳細な物性および 生成メカニズムは, 殆ど解っていない.

ここでは，アイドリング時および咸速時に観測される ナノ粒子に着目して，排気管内での粒子挙動について検 討する.

アイドリング時に観測されるナノ粒子の排気管内での 挙動を把握するために，排気管内の流れ方向に対して 3 地点（ターボチャージャー下流 $0.5 \mathrm{~m} ， 1.5 \mathrm{~m}$ および $3 \mathrm{~m}$ 位 置)における粒径分布変化を測定した. 排気管内におけ る粒径分布変化を図 2 に示す. 図の縦軸は，粒子数

(N) 濃度を示し，横軸は粒子径（Dp）をログスケール で示した. ターボチャージャー直後からサンプリング位 置が下流に行くに従って粒径 $15 \mathrm{~nm}$ 近傍に数濃度ピーク を示すナノ粒子の粒径分布は，粒径のピーク位置が大粒 径側にシフトしながら数濃度の低下が見られる。このよ うな粒径分布の変化が排気管内における粒子のどのよう な振る舞いによるものかを調べるために，ターボチャー ジャ一直後の粒径分布を初期条件として, 粒子の衝突凝 集を扱う (1) 式を用いて排気管内における粒径分布変化 を計算した.アイドリング時の排気流速は吸入空気量と

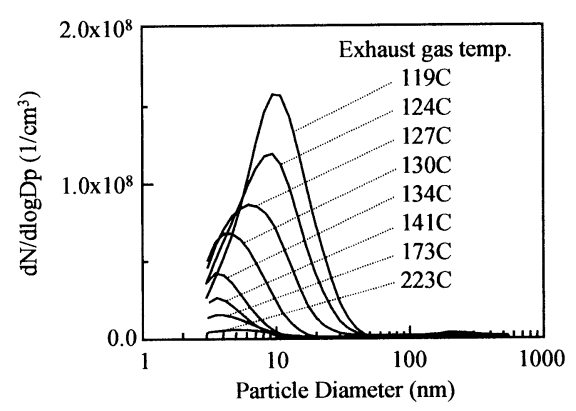

Fig.4 Effect of exhaust gas temperature on nanoparticle formation under deceleration condition

燃料量から算出した $1.6 \mathrm{~m} / \mathrm{sec}$ を用い, 凝集速度定数は, Fuchs の凝集速度定数 ${ }^{(12)}$ を用いた. この凝集速度定数は， 粒子物性には依存せずに粒径のみに依存するため, 粒子 物性が明確に解っていない今回の解析に適していると考 えられる. 計算結果を図 3 に示す. 図 2 の実験結果と比 較すると, 計算結果は実験結果にあるナノ粒子の粒径分 布変化を正確に再現している. これは, アイドリング時

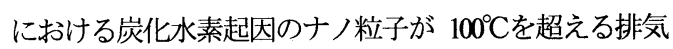
管内に既に存在しており，排気管下流に運ばれる間にブ ラウン拡散による粒子同士の衝突・凝集が主に進行した 結果であると考えられる.

次に，車両の加減速過程における減速時に観測される ナノ粒子の排気管内挙動を解析するために, 図 1 に示し た 2 段希橎器導入位置における排気管内ガス温度が $300^{\circ} \mathrm{C}$ 近傍となるエンジン運転条件 (2,500 pm-110 Nm) から燃 料カットを強制的に実施して再現性の良い減速条件を作 り出して解析した. 図 4 に然料カット後の排ガス温度低 下に応じた粒径分布変化を示す. 燃料カット直後ではナ ノ粒子の生成は全く認められないが，排ガス温度が $200^{\circ} \mathrm{C}$ 以下になると明確なナノ粒子生成が進行している ことがわかる．また，高濃度のナノ粒子は，排ガス温度 が $150^{\circ} \mathrm{C}$ 以下の排気環境において顕著に観測される.

アイドリング時および減速時における炭化水素起因ナ ノ粒子の排気管内挙動解析により，150 ${ }^{\circ} \mathrm{C}$ 以下の排ガス 温度となる排気管内においてナノ粒子が急激に生成し安 定に存在するが, $200^{\circ} \mathrm{C}$ 以上の排ガス温度ではナノ粒子 は生成しないことがわかる．このことより，Idle 時およ び咸速時のナノ粒子は, 固体核が存在せずに揮発性物質 の均質核形成により生成した $100 \%$ 揮発性物質で構成さ れていることが推察される.

3-2 ナノ粒子生成二対する理言解析炭化水素起因 ナノ粒子の排気管内における生成を理論的に解明するた めに, 2 ・3に示した理論計算モデルを用いて検討した. 
解析対象は, 図 2 に示した排気管内におけるアイドリ ング時のナノ粒子とした.

まず，アイドリング時のナノ粒子の主成分が燃料成分 の高沸点炭化水素のであることより, 主成分の均質核形 成によるナノ粒子生成の可能性を評価した. 主成分の代 表物質として燃料成分炭化水素の高沸点成分である $\mathrm{C}_{20} \mathrm{H}_{54}$ (nParaffin) の物性值を用いて検討した.

図 2 のターボチャージャー直後の排ガス温度 $113^{\circ} \mathrm{C}$ に おいて $10^{8}$ 個 $/ \mathrm{cm}^{3}$ のナノ粒子が存在するために必要な核 形成速度と $\mathrm{C}_{26} \mathrm{H}_{54}$ 濃度との関係を図 5 に示寸. $113^{\circ} \mathrm{C}$ にお ける $\mathrm{C}_{26} \mathrm{H}_{54}$ の飽和蒸気珐は 025Pa であり, 約 25ppm で飽 和となるが，核形成速度は限りなくゼロに近い值であり， 十分な核形成速度を得るためには, 排気中に $\mathrm{C}_{26} \mathrm{H}_{54}$ が 250ppm以上存在しなければならないことがわかる.

この結果を踏まえて, 排気中に $\mathrm{C}_{20} \mathrm{H}_{54}$ が 250ppm 存在 すると仮定して，アイドリング時の粒径分布変化をシミ ユレートした結果を図 6 に示す. 高濃度 (250ppm) の $\mathrm{C}_{20} \mathrm{H}_{54}$ が気相に存在するため, 十分な核形成速度が得ら れ急速に核形成が進行するが，同時に凝縮も進行し，数

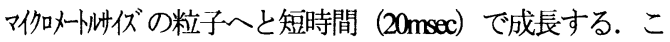
の計算結果は, アイドリング時に観測される実験結果

（図 2）を全く説明することができない.アイドリング 時に排気管内て観測されるナノ粒子の主成分は, 燃料成 分の高沸点炭化水素であるが，ナノ粒子が生成するため に必要な核を形成する物質は，これら主成分とは異なる 物性，すなわち低濃度で高い核形成速度を持ったものを 考えなければならない．

この計算結果を踏まえて, アイドリング時のナノ粒子 生成を説明することができる揮発性物質の物性を推定す る検討を実施した. 核形成速度の支配因子は，(3) 式よ り過飽和度（飽和蒸気圧）と表面張力であるため, $10^{8}$ 個 $/ \mathrm{cm}^{3} / \mathrm{sec}$ 以上の核形成速度を $1 \mathrm{ppm}$ 以下の低濃度で得る ために必要な飽和蒸気圧と表面張力との関係を調べた.

図 7 に核形成速度に及ぼす飽和蒸気圧と表面張力の関係 を示す.

このときの雾囲気温度は $113^{\circ} \mathrm{C}$ と, 揮発性物質濃度は $025 \mathrm{ppm}$ として計算した。 $10^{8}$ 個 $/ \mathrm{cm}^{3} / \mathrm{sec}$ 以上の核形成速度 を得るためには, 飽和蒸気圧として $\mathrm{C}_{20} \mathrm{H}_{54}$ の $1 / 10^{4}$ 以下で あり, 表面張力は $\mathrm{C}_{26} \mathrm{H}_{54}$ の $80 \%$ 程度である物性值を持っ た揮発性物質が存在しなければならないことがわかる.

この物性值を用いて, アイドリング時の粒径分布変化 をシミュレートした結果を図 8 に示す。仮定した物質の 初期濃度は, 025ppm とし, 排気バルブ通過時には筒内 で生成した Sootの存在も仮定して計算した.

計算結果は，アイドリング時の排気管内で観測される 粒径分布を正確に再現できていることがわかる。すなわ

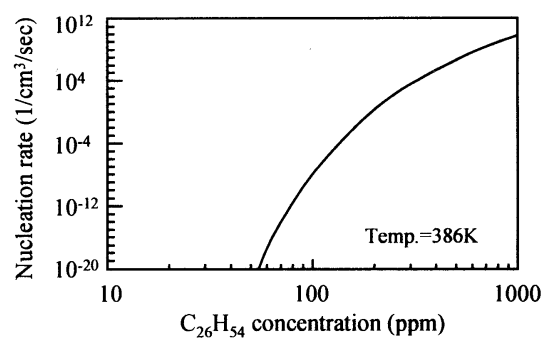

Fig.5 Relationship between $\mathrm{C}_{26} \mathrm{H}_{54}$ conc. and nucleation rate

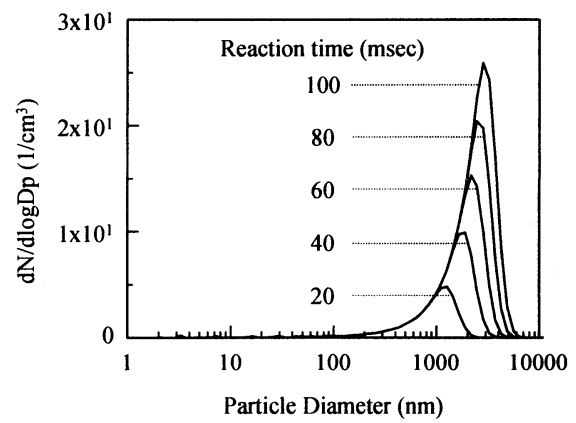

Fig.6 Change of particle size distributions simulated by considering nucleation of $\mathrm{C}_{26} \mathrm{H}_{54}$

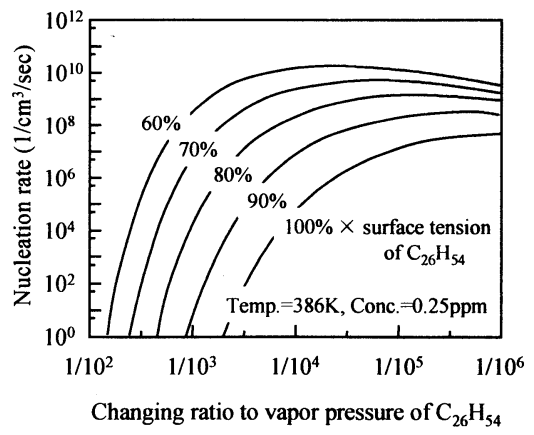

Fig.7 Effect of vapor pressure and surface tension on nucleation rate

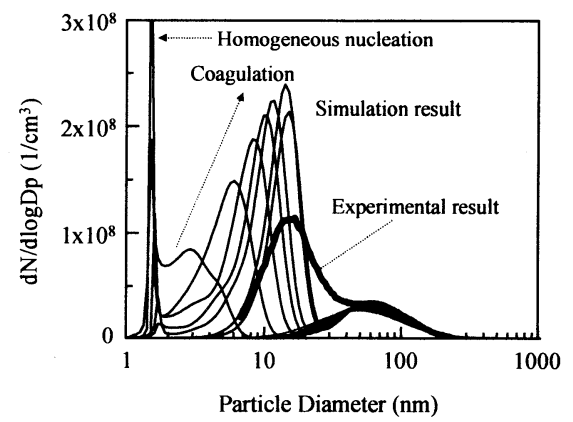

Fig.8 Simulated particle size distributions under idling condition compared to experimental result 
ち，炭化水素起因ナノ粒子の主成分とは異なる均質核形 成に寄与する揮発性物質がアイドリング時および咸速時 のエンジン排気中に存在していると考穴られる.

$3 \cdot 3$ ナノ粒子の核形成物質 $30 \mathrm{~nm}$ 以下のナノ粒子 を化学分析するために図 1に示した MOUDIおよびNanoMOUDI を用いて粒径別に粒子をサンプリングした. 詳 細な化学分析を行うためには, 数マイクログラム程度の サンプル量が必要となるため, 数時間エンジンを定常運 転する必要がある.このため, 過渡運転過程である減速 を模擬するために, 油・水温は, $80^{\circ} \mathrm{C}$ に保ち, 燃料カッ 卜条件であるモータリング（モーターでエンジンを強制 的に回転させる. エンジン回転数：1,250pm）条件で粒 子サンプリングを実施した.

アイドリング時および減速を模擬したモータリング時 に排出される粒子（図 9）を粒径別に捕集し，ナノ粒子 の粒径領域である $18 \mathrm{~nm}-36 \mathrm{~nm}$ の粒子区分サンプルを加熱 脱着 GCMS を用いて分析した結果を図 10 に示す．比較 のために，使用したエンジンオイルと使用然料の $310^{\circ} \mathrm{C}$ 蒸留残分のトータルイオンクロマトグラムも併せて示す. Idle 時と減速を模擬したモータリング時のナノ粒子のク ロマトグラムは大きく異なっている. Idle 時の場合, 燃 料の高沸点成分（ $310^{\circ} \mathrm{C}$ 蒸留残分）とエンジンオイルの 混合したクロマト形状を示し，モータリング時では，燃 料の寄与は無くエンジンオイルの影響を強く受けたクロ マト形状である.この結果は, 前報 (ので示した Idle 時お よびモータリング時に排出される全ての粒子状物質から 抽出された SOF (Soluble organic fraction) 成分の GCMS 分 析結果と一致しており, ナノ粒子の主成分は SOF 成分 と大きな違いがないことがわかる.

次に，アイドリング時および減速時におけるナノ粒 子の核形成メカニズムを検討する上で重要な化学成分 の情報を得るために，高い質量分解能を持ち，GC/MS では測定できない高分子量物質の測定が可能な TOFSIMSによる分析を実施した. 図 11 にアイドリング時 およびモータリング時における粒径別粒子サンプルに 含まれる含酸素系炭化水素と脂肪族炭化水素のフラグ メント $\left(\mathrm{C}_{3} \mathrm{H}_{5} \mathrm{O}^{+}\right.$と $\left.\mathrm{C}_{4} \mathrm{H}_{9}{ }^{+}\right)$イオンカウントと $\mathrm{C}_{3} \mathrm{H}_{7}{ }^{+}$イ オンカウントとの比率を示す. $\mathrm{C}_{3} \mathrm{H}_{7}^{+}$イオンは, 全て の炭化水素からフラグメントとして計測されることか ら, 全炭化水素量で規格化するために用いている. 減 速過程を模擬したモータリング時は, 揮発性粒子しか 存在しないため, $50 \mathrm{~nm}$ 以上の粒子が極端に少ないた め, 56nm以上の測定結果は存在しない.

アイドリング時の場合, $\mathrm{C}_{3} \mathrm{H}_{5} \mathrm{O}^{+}$は粒径の低下と共に 存在比率が増加するが, $\mathrm{C}_{4} \mathrm{H}_{9}^{+}$は明確な粒径依存性が 見られない.これに対して，モータリング時の場合は，

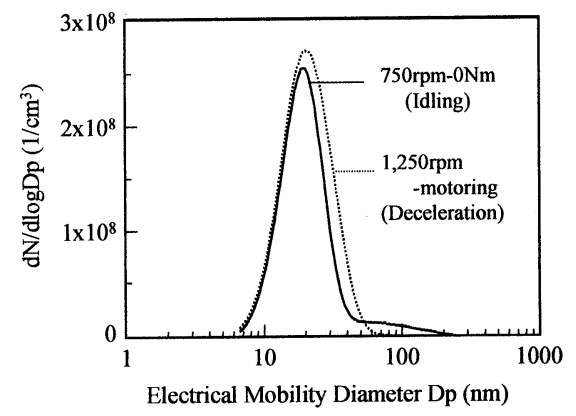

Fig. 9 Averaged number size distributions derived from SMPS at 750rpm-0 Nm (idling) and 1,250rpm-motoring (deceleration)

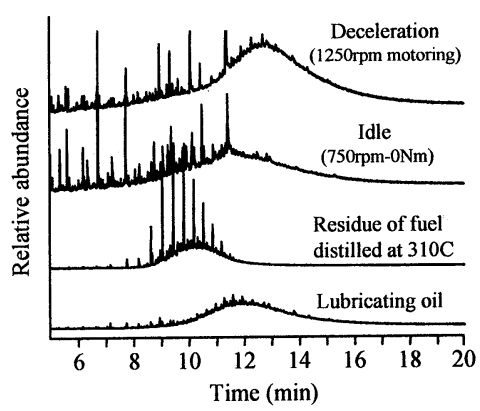

Fig.10 GC/MS total ion chromatograms of 18-36nm sizeseparated nanoparticle samples under idling and deceleration conditions

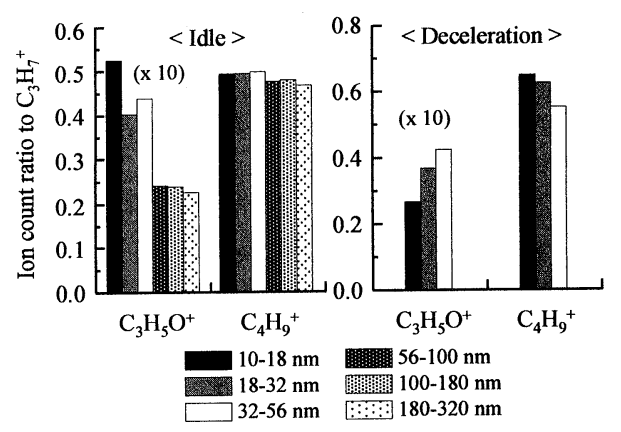

Fig.11 Abundance ratios both of $\mathrm{C} 3 \mathrm{H} 5 \mathrm{O}+$ that is a fragment ion of oxygenated hydrocarbons and $\mathrm{C} 4 \mathrm{H} 9+$ that is a fragment ion of aliphatic hydrocarbons to $\mathrm{C} 3 \mathrm{H} 7+$ in each size-separated particle sample: (a) under idling condition and (b) under deceleration condition

粒径の低下と共に $\mathrm{C}_{4} \mathrm{H}_{9}^{+}$の存在比率増加が見られる. 粒径の低下と共にイオンカウント比が増加することは, そのイオンの親分子が非常に低い蒸気圧を有し, 揮発 


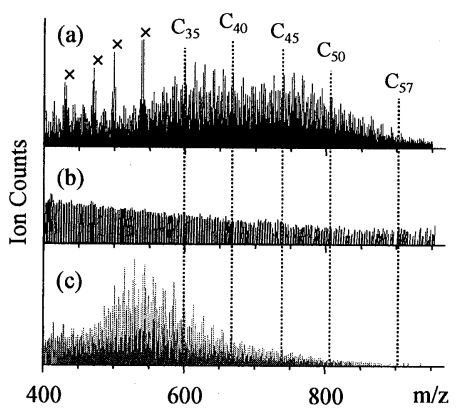

Fig.12 TOF-SIMS ion count weighted mass distributions of three samples: (a) 10-18nm size-separated particle sample under deceleration, (b) that under idling condition and (c) the lubricating oil sample

性ナノ粒子の核形成に寄与した物質であると考えられ る.アイドリング時のナノ粒子には, $\mathrm{C}_{3} \mathrm{H}_{5} \mathrm{O}^{+}$をフ グメントイオンとして生成する含酸素系炭化水素が核 形成物質と考えられる. また，アイドリング時のナノ 粒子生成特性は, 燃料の蒸留性状に依存する ${ }^{(の こ と よ ~}$ り, 含酸素系炭化水素は燃料成分炭化水素の低温酸化 物 (燃料成分炭化水素の骨格を持った過酸化物) であ ると推定される. モータリング時のナノ粒子には, $\mathrm{C}_{4} \mathrm{H}_{9}{ }^{+}$をラグメントイオンの親分子としてエンジン オイル由来の脂肪族系炭化水素の存在が示唆される. モータリング時の場合, フラグメントイオンの情 報だけでは脂肪族系炭化水素の詳細な物性を把握する ことができない.このため, 脂肪族系炭化水素の親イ オンを検出するために, $\mathrm{Ag}$ (銀) 蒸着法を用いた TOF-SIMS 分析 ${ }^{(14)}$ をータリング時における $10 \mathrm{~nm}-$ $18 \mathrm{~nm}$ 粒径区分のサンプルに対して実施し，比較のた めにアイドリング時のナノ粒子サンプルとエンジンオ イルに対しても実施した. 図 12 に三つのサン゚ルに 対する TOF-SIMS で検出される親イオンの分子量分布 を示す. モータリング時のナノ粒子サンプルは, アイ ドリング時のサンプルおよびェンジンオイルの質量分 布とは異なり, 炭素数 $35\left(\mathrm{C}_{35}\right)$ 以上の脂肪族炭化水 素の存在が顕著に現れている.これは，モータリング 時，すなわち減速時におけるナノ粒子の核形成物質と して, $\mathrm{C}_{35}$ 以上のエンジンオイル由来の脂肪族炭化水 素が考えられる.

以上のことより，理論計算によって得られた核形成物 質の性質を満足する成分として, 蒸気圧が $\mathrm{C}_{26} \mathrm{H}_{54}$ に比べ 確実に低いと考えられる高沸点炭化水素の低温酸化物や $\mathrm{C}_{35}$ 以上の脂肪族炭化水素類がナノ粒子の詳細物性解析 により抽出された.

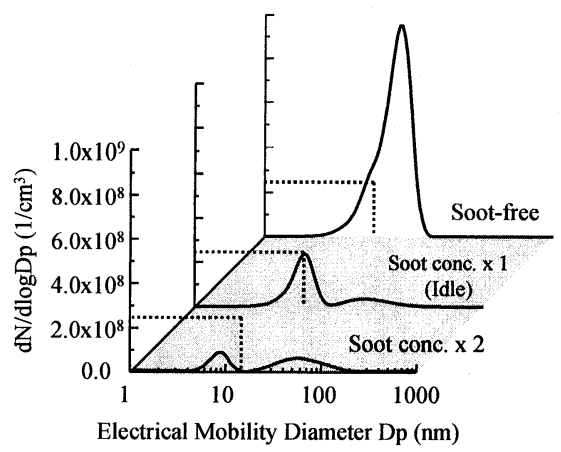

Fig.13 Estimated effect of soot concentration on the formation of nanoparticles

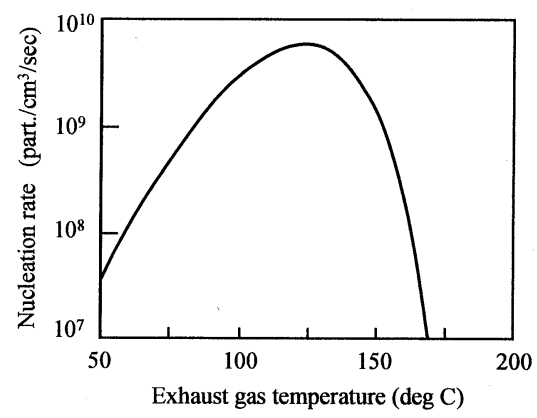

Fig.14 Estimated temperature dependency of nucleation rate of the volatile material which has $1 / 10,000$ of $\mathrm{C}_{26} \mathrm{H}_{54}$ saturation vapor pressure and $80 \%$ of $\mathrm{C}_{26} \mathrm{H}_{54}$ surface tension

\section{3-4 ナノ粒子生成特性の理論解析 理論計算から算} 出された揮発性核形成物質の物性值を用いて，ナノ粒子 の生成に及ぼす Soot濃度と排ガス温度の影響を検討した.

図 13 にナノ粒子生成に及ぼす Soot 濃度の影響を示す. Soot 濃度は, ナノ粒子の生成を支配しており, Soot が存 在しない条件では高い数濃度のナノ粒子が生成する.こ れは, ディーゼル排気後処理システムの一つである DPF

(Diesel particulate filter) 下流ではナノ粒子が生成し易い排 気環境となるため, ナノ粒子の核形成に寄与する高沸点 炭化水素類の酸化促進が重要となることを示唆している.

図 14 に揮発性物質の核形成速度と排ガス温度との関 係を示す. 核生成速度は $120^{\circ} \mathrm{C}$ 近辺で最大となっており, その両側では核生成速度が低下している. 高温側の核形 成速度の低下については飽和蒸気圧が高くなって過飽和 度が小さくなることにより，低温側については表面張力 が高くなり核生成するために必要なエネルギーが増大す ることが主な影響因子である. 排ガス温度が $170^{\circ} \mathrm{Cから}$ $120^{\circ} \mathrm{C}$ に低下する過程での核形成速度の急激な増加は, 図 4 に示した減速時のナノ粒子生成特性と良い一致を示 
しており，車両排気におけるナノ粒子生成では，排ガス 温度が高温から低温に下がる高温側の核形成速度の変化 が鍵を握る.これは，揮発性物質の核形成が積極的に進

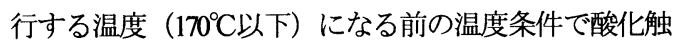
媒を利用した完全酸化を行うことがナノ粒子生成抑制に は効果的であることを示している.

\section{4. 結 語}

ディーゼルエンジンのアイドリング時および减速時 に排出される炭化水素起因ナノ粒子の詳細物性を把握 し，生成メカニズムを解明することを目的としてエン ジン実験，理論解析および物性解析を実施し，以下の 結論を得た.

1. アイドリング時および減速時に観測される炭化 水素起因ナノ粒子は， $150^{\circ} \mathrm{C}$ 以下の排ガス温度と なる排気管内において急激に生成し安定に存在 するが， $200^{\circ} \mathrm{C}$ 以上の排ガス温度条件では排気管 内に存在しない.

2. アイドリング時および減速時のナノ粒子は, 固 体核が存在せずに揮発性物質の均質核形成によ り生成した $100 \%$ 揮発性物質で構成されているこ とが推察される.

3. 理論解析により, 炭化水素起因ナノ粒子の主成 分とは異なる均質核形成に寄与する揮発性物質 がアイドリング時および減速時のエンジン排気 中に存在していると考えられた.このような揮 発性物質の物性を算出し，その物性值は，飽 和蒸気圧として $\mathrm{C}_{20} \mathrm{H}_{54}$ の $1 / 10^{4}$ 以下であり，表面 張力は $\mathrm{C}_{20} \mathrm{H}_{54}$ の $80 \%$ 程度である.

4. 詳細物性解析により, 理論計算によって得られ た核形成物質の物性を満足する成分として，ア イドリング時では燃料成分高沸点炭化水素の低 温酸化物，減速時ではエンジンオイル由来の $\mathrm{C}_{35}$ 以上の脂肪族炭化水素類が抽出された.
5. ディーゼル排気後処理システムの一つである DPF 下流ではナノ粒子が生成し易い排気環境と なるため, 炭化水素起因の揮発性物質の核形成

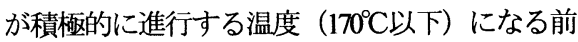
の温度条件で酸化触媒を利用した核形成物質の 完全酸化を行うことがナノ粒子生成抑制には効 果的であることが考えられた。

\section{文梋}

(1) Nakano, M at al., Formation of diesel nanoparticles (first report)-Effect of hydrocarbons on nanoparticle formation, JSAE Technical Paper, (2003), 20035130.

(2) Sakurai, $\mathrm{H}$ a al, On-line measurements of diesel nanoparticle composition and volatility, Atoms Environ, (2003), Vol. 37, No. 9-10, pp. 1199-1210.

(3) Andersson, J. at al, Fuel and lubricant effects on nuckeation mode particle emissions from a Euro III light duty diesel vehicle, SAE Technical Paper Series, (2004), 2004-01-1989.

(4) Marioq, M.M. a al, The effects of the catalytic converter and fuel sulfur level on motor vehicle particulate matter emissions: Light duty diesel vehiches, Environ. Sci Technol, (2002), Vol. 36, No. 2, pp. 283-289.

(5) Kubo, S et al, Formation of diesel nanoparticles (seoond report)-Effect of sulfate on nanoparticle formation, JSAE Technical Paper, (2003), 20035132

(6) Kubo, S et al., Formation characteristics of diesel nanoparticles, Transactions of the Japan Society of Mechanical Engineers Series B, to be submitted.

(7) Abdul-Khalek, I. et al., Nanoparticle growth during dilution and cooling of diesel exhaust: Experimental investigation and theoretical assensment, $S A E$ Technical Paper Series, (2000), 2000-01-0515

(8) Mathis, U, Influencing parameters of nanoparticle formation from diesel

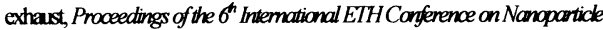
Measurements, (2002)

(9) Abdu-Khalek, L., Solid and total exhast particle mas, number, and size emissions from adiesel powered generator, Proceedings of the $8^{\text {h }}$ Intermational ETHConference on Combustion Generated Particles, (2004)

(10) Montaiir, R.M. et al, Thermal Conditioning of Exhaust Gas: Potential for Stabilizing Diesel Nano-Particles, SAE Technical Paper Series, (2005), 200501-0187.

(11) Friedlander, S. K., Smoke, Dust, and Haxe: Fundamentals of Aerosol Dynamics, (2000), Oxford University Press, Oxford.

(12) Fucts, N.A., Mechanics of Aerasols, (1964), Pergamon, New York

(13) Seinfeld, J.H and Pandis, S.N., Atmaspheric chemistry and physics, (1998), Wiley-Interscience, New York

(14) Inoue, M \& al, Molecular Weight Evaluation of Poly(dimethilsiloxane) on Solid Surfaces Using Silver Deposition/TOF-SIMS, Anahtical Sciences, (2004), Vol. 20, pp. 1623-1628. 